\title{
Prevalence of Residual B Cell Function and Its Metabolic Consequences in Type 1 (Insulin-Dependent) Diabetes
}

\author{
S. Madsbad \\ Hvidøre Hospital, Klampenborg, Denmark
}

\begin{abstract}
Summary. Several reports suggest that most patients have surviving $B$ cells at the onset of Type 1 (insulin-dependent) diabetes. After starting insulin therapy, most have a transient improvement in B cell function which peaks between 2 and 6 months after diagnosis. Thereafter B cell function declines. However, even after 2 years most patients still display some residual $B$ cell function. During the following $10-15$ years, the prevalence of residual B cell function decreases to about $15 \%$ and stays at this level. At present it is unknown why patients with Type 1 diabetes have different degrees of $B$ cell function after several years of disease. Age at onset is of importance for the first 10-15 years of disease. Patients with late onset have a higher prevalence of retained B cell function than patients with early onset. Both at the onset of disease and after the initial remission period, an improvement in glycaemic control results in improved B cell function but the effect is transient. The occurrence of islet cell antibodies, islet cell surface antibodies and the many abnormal cellular immunological parameters found in Type 1 patients have not been correlated to
\end{abstract}

the degree of B cell function. The metabolic importance of even minimal endogenous insulin secretion on intermediate metabolism has been clearly demonstrated during insulin withdrawal. During hypoglycaemia, patients with B cell function have a greater glucagon and pancreatic polypeptide response than patients without. The nadir and recovery of blood glucose do not differ, but rates of lipolysis and ketogenesis are exaggerated in those without B cell function. Residual B cell function is clearly linked to clinical remission but seems to have little effect on metabolic control in daily life after years of diabetes. Only patients with considerable B cell function have markedly better metabolic control than patients without B cell function, but those with residual B cell function need a smaller daily dose of insulin to obtain the same degree of control. Whether residual $B$ cell function protects against or delays the development of late complications is not clear.

Key words: B cell, C-peptide, Type 1 diabetes, hypoglycaemia
The development of the C-peptide assay has provided the tool for direct studies of endogenous insulin secretion in Type 1 (insulin-dependent) diabetic patients. In 1967, Steiner et al. showed that proinsulin is converted within the pancreatic B cells to insulin and C-peptide [1, 2], which are secreted into the portal circulation in equimolar quantities along with a small amount of proinsulin [3-5]. C-peptide is not extracted to any significant degree by the liver $[6,7]$, and several studies substantiated C-peptide measurement as a reliable parameter of B cell function [3-14].

The aim of the present review is to focus on the prevalence of residual $\mathrm{B}$ cell function and factors of importance for preserving, and improving, endogenous insulin secretion. The metabolic importance of residual B cell function during insulin withdrawal, during insulininduced hypoglycaemia and during every-day life will be discussed.

\section{C-Peptide Measurements in the Assessment of B Cell Function}

In 1972 Block et al. [15], using C-peptide measurements, supported the view that Type 1 diabetes is characterized by a total deficiency of endogenous insulin secretion. Cpeptide was undetectable in newly diagnosed untreated Type 1 patients and in those who had received insulin for more than 5 years. Later Block et al. [16] showed that the lack of endogenous insulin secretion at onset reflected a transient impairment rather than total destruction of the B cells.

Subsequently more sensitive C-peptide assays have shown measurable amounts of plasma C-peptide in nearly all patients before the start of insulin treatment [17-20]. On average, levels correspond to about $20 \%$ of the mean maximal value in normal subjects $[19,20]$. After initiation of insulin therapy a doubling of B cell 
secretory capacity has been shown after 7 days [20] and maximal residual $B$ cell function has been demonstrated after 2-6 months $[20,21]$. On average, two-thirds of this improvement occurred during the first 14 days after starting insulin [20]. Declining B cell function has been shown after 6 months of insulin treatment $[19,21]$. In contrast, Ludvigsson and Heding [17] found identical C-peptide concentrations at onset and 1 month later with a steady decline thereafter. However, they compared C-peptide values at onset with fasting C-peptide values that to some extent depend on the concomitant blood glucose concentration [22].

In 267 patients between 10 and 20 years of age at onset [23] residual B cell function was demonstrated in all but one with diabetes of less than 2 years' duration. The prevalence of residual $\mathrm{B}$ cell function was $66 \%$ in patients with duration from 0 to 4.9 years. Thereafter, it declined to about $15 \%$ in patients with duration from 10 to 35 years [23]. The magnitude of residual B cell function declined from a mean of $0.27 \mathrm{nmol} / 1$ after $0-4.9$ years to $0.10 \mathrm{nmol} / 1$ in patients with more than 10 years duration (post-stimulatory C-peptide, normal range: $0.86-1.88 \mathrm{nmol} / 1)$. This has been found in both children [24] and adults [25], although two other reports claim a higher prevalence of residual $\mathrm{B}$ cell function $[26,27]$. The most likely explanation for the higher prevalence in the first study [26] is a difference in the C-peptide assay used. In the study by Eff et al. [27], the patients with Type 1 diabetes examined had more than 18 years duration of disease, and were all treated with $<0.5$ IU insulin $\cdot \mathrm{kg}$ body weight ${ }^{-1} \cdot 24 \mathrm{~h}^{-1}$ : the prevalence of residual B cell function was $24 \%$ in this highly selected group.

Thus, during the first 2 years of diabetes most patients will have residual $\mathrm{B}$ cell function. Thereafter the prevalence declines to about $15 \%$ after 10 years. After 10 years, no further decline in prevalence seems to occur. This conclusion is substantiated by the earlier morphological studies by Gepts and Mey De [28], who also showed small new islets in the distal parts of the excretory ducts in cases of recent onset. The relevance of this regeneration to the temporary improvement of $\mathrm{B}$ cell function seen after initiation of insulin treatment is unknown.

\section{Factors Affecting Residual B Cell Function}

\section{Age at Onset:}

In one study, there was a significant correlation between age and C-peptide concentration in plasma at onset of disease, suggesting that the B cell destruction is less pronounced in patients who are older at diagnosis [29].

The prevalence of residual $\mathrm{B}$ cell function has been compared in patients between 10-20 years of age at onset and those with onset between 30 and 40 years [23].
Residual B cell function during the first 15 years was more common in the late-onset group. Thereafter, no difference was demonstrated between the two groups. Also in children, age at onset has been shown to influence residual B cell function [24]. In one study, patients with onset after age 15 years had a higher prevalence of residual $\mathrm{B}$ cell function after 18 years of diabetes than children with onset before the age of 15 years [27].

\section{Degree of Metabolic Control}

Ludvigsson and Heding [24] compared the duration of initial ketonuria in patients with and without B cell function and found it longer in patients without $B$ cell function. Unfortunately, the group with residual B cell function had both shorter duration of disease and an older age at onset.

The effect of initial strict blood glucose control on B cell function has been compared with that seen after conventional treatment [30]. For 11 consecutive days after diagnosis, the strict control group was treated with multiple injections of rapid-acting insulin aiming at normoglycaemia. The conventionally-treated group was given insulin once or twice daily from day 1 . From day 11 , both groups were treated conventionally. On day 14, C-peptide secretion was found to be $61 \%$ greater in the group under strict control compared with the conventionally treated subjects. In contrast to the results of Mirouze et al. [31], this effect was transient and no difference in B cell function was found after 3 and 6 months when the two groups had equivalent control and were being treated with the same daily dose of insulin. Patients in the conventionally treated group also improved their B cell function during the first 14 days of treatment, and B cell function was maximal after 3 months. Mirouze et al. [31] found a more frequent and a longer-lasting recovery of B cell function after strict glycaemic control compared with conventional treatment. The explanation for this discrepancy is not clear.

In another study of patients past the initial remission period with a fasting C-peptide above $0.07 \mathrm{nmol} / 1$ (normal range: $0.18-0.63 \mathrm{nmol} / 1$ ), strict glycaemic control for 1 week increased C-peptide secretion after a test meal [32] by an average of $44 \%$. Patients with initial Cpeptide values below or equal to $0.07 \mathrm{nmol} / 1$ were unaffected by strict glycaemic control. After 3 weeks as outpatients on conventional insulin treatment, the amount of insulin secreted in the first group was not different from that observed during the initial test, and all but one had less B cell function than after 1 week of strict control. These results indicate that $B$ cell function in insulin-dependent patients is related to degree of glycaemic control, but that a short-term period of strict control does not appear to influence the long-term outcome of $B$ cell function.

Why B cell function improves when the hyperglycaemic stress is relieved is still not clear. A possible mechanism may be a modification of the entero-insular 
axis with an increased responsiveness of gut hormones which potentiate the insulin response to oral glucose. Gastric inhibitory polypeptide (GIP) has been the main candidate suspected of exerting the incretin effect, but no augmented GIP response has been found after strict control [33]. Another possibility is that strict control suppresses endogenous insulin secretion. Consequently, larger stores of insulin might accumulate for secretion when the B cells are stimulated [34].

\section{Immune Mechanisms in Relation to B Cell Function}

In one study, an increased incidence of detectable Cpeptide was demonstrated in patients with HLA$\mathrm{B} 8, \mathrm{BW} 15$ [35], although the groups had different ages at onset and different durations of disease. Two other studies have not shown any correlation between B cell function and HLA-antigens [36, 37].

The prevalence of islet cell antibodies (ICA) is similar to that of residual B cell function [38, 39]. It is therefore tempting to postulate an association between ICA and prevalence of residual $\mathrm{B}$ cell function. However, in three studies no relationship between persistence of ICA and residual $B$ cell function has been observed [40-42]. Islet cell surface antibodies are independent of ICA [44] but strictly related to duration of disease [43, 44]. Again no correlation was found between persistence of islet cell surface antibodies and B cell function [44].

There is evidence for cell mediated autoimmunity and cytotoxicity in the pathogenesis of Type 1 diabetes [45-50], and it is noteworthy that patients with particularly low suppressor cell activity at onset showed the least B cell recovery in the remission period [37]. After several years of disease, no difference in suppressor cell activity was found between patients with and without residual $\mathrm{B}$ cell function [51].

Evidence that Type 1 diabetes is an autoimmune disease has prompted investigation of immunotherapy and it has been suggested that corticosteroid therapy may partially preserve endogenous insulin secretion in newly diagnosed patients [52].

Insulin-binding antibodies have been implicated in $B$ cell destruction [53-55]. Several studies have correlated $B$ cell function and insulin-binding antibodies [27, $35,56-58]$ and, except for one study, no significant correlations have been found [35]. In that study the highest titres of antibodies were found in the group without B cell function, but these patients had also had diabetes for longer and were younger at onset.

\section{Qualitative Function of Residual B Cells in Insulin-Dependent Patients}

During initial treatment for ketoacidosis the fall in blood glucose was followed by a significant parallel decrease in plasma C-peptide [20]. In patients with dia- betes for less than 5 years, diurnal profiles of C-peptide were highly correlated with plasma glucose $[21,30,56$, 59-63]. Also, during insulin-induced hypoglycaemia, B cells were sensitive to changes in glucose below the normal range [63]. On the other hand, it has been reported that $B$ cells failed to respond to glucose concentrations up to $56 \mathrm{mmol} / 1[11,18,26,64,65]$; however, they did respond to arginine [64], tolbutamide [18] and glucagon $[18,65]$, suggesting a decrease in glucose sensitivity.

A single study suggests that the process that stops insulin secretion after stimulation may be defective in Type 1 patients past the period of remission. Twentyfour hours of normoglycaemia had no influence on this qualitative B cell defect [66].

Few studies have examined all the secretory products of B cells $[67,68]$. At the time of diagnosis, and before the start of insulin treatment, a fivefold higher molar ratio of proinsulin: C-peptide has been shown compared with that of normal subjects [67]. The amount of proinsulin secreted and the molar proinsulin: C-peptide ratio correlated positively with the magnitude of residual B cell function but not with blood glucose concentrations. During the initial 14 days of treatment, proinsulin secretion increased in parallel with an improvement of $B$ cell function despite a declining glycaemic stress on the B cells. Therefore, the magnitude of B cell function seems to be the primary factor regulating the amount of proinsulin secreted [67].

After the remission period, Heding [68] found measurable amounts of proinsulin in 31 patients, whereas only 19 had measurable amounts of C-peptide. This supports the view that the exhausted pancreas secretes immature granules with an excess of proinsulin and, in some situations, only proinsulin. However, the presence of proinsulin-binding antibodies in the last study may explain the discrepancy between the two investigations $[67,68]$ since antibodies interfere with the proinsulin assay and prolong the half-life of proinsulin in plasma [68].

\section{The Metabolic Importance of Residual B Cell Function in Insulin-Treated Patients}

\section{Insulin Withdrawal:}

The mutual relationship between $\mathrm{B}$ cell function and the degree of glycaemic control, together with the fact that patients with residual $\mathrm{B}$ cell function are given smaller doses of insulin than those without, have made it difficult to assess the exact effect of endogenous insulin secretion on intermediate metabolism. In an insulin withdrawal study only one parameter, the residual B cell function, was different in the two groups studied [59]. The group with residual $\mathrm{B}$ cell function had blood glucose levels of about $9 \mathrm{mmol} / 1$ after $4-12 \mathrm{~h}$ of insulin deprivation in contrast to the group without B cell function in whom blood glucose increased steadily to about 
$17 \mathrm{mmol} / 1$ after $12 \mathrm{~h}$ of insulin deprivation. Likewise, 3hydroxybutyrate (5.4 versus $1.4 \mathrm{mmol} / \mathrm{l}$ ), glycerol, and non-esterified fatty acids were higher in the group without $B$ cell function at the end of the study.

During the first $10 \mathrm{~h}$ of insulin withdrawal, patients without B cell function decompensated faster despite similar peripheral free insulin concentrations. The effect of endogenous insulin thus seems to be due to a direct effect on the liver [69]. Glucagon concentrations were similar in the two groups. Therefore, different A cell function in the two groups cannot directly explain the differences in metabolic responses [69].

\section{Hypoglycaemia}

Several authors have found a lack of glucagon response to hypoglycaemia in Type 1 patients [70-74], but Samols and Harrison's concept [75] of an intra-islet A-B cell interaction prompted us to see whether residual B cell function influences the function of the other cell types in the islets of Langerhans during hypoglycaemia $[63,76-78]$ and, secondly, whether a residual $B$ cell function protects against severe hypoglycaemia or is important for recovery [63].

A glucagon response to hypoglycaemia was found in all patients, but was greatest in patients with residual $B$ cell function although still subnormal. There was no overlap between the diabetic groups with and without B cell function. The exact physiological mechanism responsible for this difference in glucagon response is unclear. An A-B cell interaction via the D cells is less likely as no difference was found in somatostatin response between the two groups [77].

Reports from Shima et al. [70] and Raynolds et al. [71], demonstrating a more normal glucagon response to hypoglycaemia in insulin-treated Type 2 (non-insulindependent) diabetic patients compared with that of diabetic patients without B cell function, support the importance of residual $B$ cell function for the glucagon response to hypoglycaemia.

The pancreatic polypeptide response was also greater in our group with residual B cell function when compared with the group without B cell function [76]. The nadir and rate of recovery of glucose were identical in the diabetic patients with and without $\mathrm{B}$ cell function, despite the differences in glucagon responses [63]. This may be explained by the normal response of adrenaline in both groups [72]. The responses of cortisol and growth hormone were identical in the two groups [63]. Both lipolysis and ketogenesis were exaggerated and prolonged in the group without B cell function even though no difference was found in peripheral insulin concentrations [63].

\section{Metabolic Importance of Residual B cell Function at Diagnosis and During Daily Life}

At diagnosis and before the start of insulin treatment, no correlation between B cell function and blood glu- cose concentration or the degree of ketonuria has been demonstrated, but not all patients were fasting, which may explain the lack of correlations $[17,20]$. At the onset C-peptide was inversely correlated to glycosylated haemoglobin [18].

After starting insulin treatment, there was a two-tothreefold improvement in B cell function over the first 14 days [20]. In the same time period, glycosuria and mean daily blood glucose declined from about 60 to 10 $\mathrm{g} / 24 \mathrm{~h}$ and 12 to $8 \mathrm{mmol} / 1$ respectively, despite a constant average daily dose of insulin. Therefore it is likely that the improvement reflects increased endogenous insulin secretion, although an increase in insulin sensitivity is also possible [79].

The metabolic importance of preserved B cell function can also be seen from the fall in insulin dose and the concomitant increase in diurnal mean C-peptide from the onset of disease to the maximal degree of remission $[17,20,21,30,52,62,80]$. After the remission period, patients with the greatest increase in insulin dose had the most pronounced decrease in B cell function [21]. Despite this increase in insulin dose, mean blood glucose during the day increased concomitantly with the decreasing $B$ cell function during the first year of diabetes. A significant inverse correlation was found between C-peptide and the degree of glycaemic control, as expressed by diurnal mean blood glucose and mean amplitude of glycaemic excursions (MAGE) in patients with the same duration of disease [21]. Comparable results have been obtained in patients with longer durations of disease $[35,56,60,61]$.

Several cross-sectional studies have assessed the influence of persistent B cell function on metabolic control in long-term diabetics. Conflicting results have been presented [26, 56-59, 70, 71, 81-84]. In 210 Type 1 diabetic outpatients [84], no difference was found in control between patients with and without $B$ cell function. Patients with endogenous insulin secretion were treated with a smaller daily dose of insulin and more often with only one daily dose compared with patients without B cell function. Only a subgroup with a post-stimulatory C-peptide level exceeding $0.30 \mathrm{nmol} / 1(\sim 25 \%$ of that found in normal subjects) had better metabolic control than patients without $\mathrm{B}$ cell function. In 65 patients with $B$ cell function, there was a significant inverse correlation between C-peptide and glycosuria [84]. This may be a direct consequence of endogenous insulin secretion, but could also be explained by the relationship between glycaemic control and B cell function [30,32]. From this study, it seems that there is no obvious effect of residual B cell function on glycaemic control in most patients with more than 5 years of disease. Additional data supporting this conclusion come from work by Grajwer et al. [26] in children and adolescents.

Yue et al. [57] classified patients as labile or nonlabile according to their diabetic control 12 months before study. Fifty-eight percent of non-labile patients had residual $\mathrm{B}$ cell function compared with none in the la- 
bile group. Those with residual B cell function were on average 21 years older at onset, had better glycaemic control, and required 30\% less insulin when compared with patients without $B$ cell function. A negative inverse correlation was found between the degree of glycaemic control expressed by individual $\mathrm{M}$-values and the response of C-peptide to glucose.

Residual B cell function correlated negatively with glycosylated haemoglobin ${ }_{1 \mathrm{c}}$ in non-obese Type 1 patients, but not in obese Type 1 patients (average weight $156.7 \%$ of ideal body weight) where insulin resistance may determine glucose intolerance [58].

In another study of 16 patients, Ikeda et al [83] were unable to demonstrate a correlation between C-peptide and degree of control or with the daily dose of insulin.

In theory, the metabolic influence of residual $B$ cell function could be mediated through an A-B cell interaction, resulting in a relatively more normal glucagon concentration in patients with residual B cell function. However, neither the fasting glucagon nor the meal induced responses differ in patients with and without B cell function [85].

Thus, during every-day life residual B cell function must be of considerable magnitude before it makes any difference to the ease of glycaemic control. The effect of low endogenous insulin secretion can be overriden by diet, quality of treatment and exercise.

It is of great interest to know whether residual B cell function protects against or delays the development of late complications. In a study of 544 Type 1 patients with up to 40 years duration the degree of retinopathy was not different between patients with and without B cell function (Madsbad, unpublished observations).

Smith et al. [86] measured the presence or absence of residual insulin secretion in 11 Type 1 diabetic patients with severe complications after less than 25 years duration and in nine patients with no complications after more than 25 years duration and found one patient from each group with residual B cell function. Owing to the few patients with residual B cell function in both groups, this study cannot assess the importance of residual B cell function for the development of late complications. Bodansky et al. [87] also measured prevalence of residual $\mathrm{B}$ cell function in 37 Type 1 diabetic patients with late complications and 20 patients without complications. Unexpectedly, they found a higher prevalence of residual B cell function among patients with complications. A fourth study by Eff et al. [27] of patients with long duration ( $>18$ years) and a low insulin requirement $(<0.5 \mathrm{IU} / \mathrm{kg}$ body weight) found significantly less severe retinopathy in patients with residual $\mathrm{B}$ cell function.

These observations suggest that preserved B cell function is of minimal or no importance in most patients in protecting against development of late complications. Against this conclusion it should be noted that the studies are cross-sectional and the actual life-span of the B cells in the patients classified as non-secretors is unknown.

\section{References}

1. Steiner DF, Oyer PE (1967) The biosynthesis of insulin and a probable precursor of insulin by a human islet cell adenoma. Proc Natl Acad Sci 57: 473-480

2. Steiner DF, Clark JL, Nolan C, Rubenstein AH, Margoloash E, Aten B, Oyer PE (1969) Proinsulin and the biosynthesis of insulin. Recent Prog Horm Res 25: 207-282

3. Rubenstein AH, Clark JL, Melani F, Steiner DF (1969) Secretion of proinsulin C-peptide by pancreatic beta-cells and its circulation in blood. Nature 224: 697-699

4. Heding LG, Larsen UD, Markussen J, Jørgensen KH, Hallund O (1974) Radioimmunoassay for human pork and ox C-peptide and related substances. Horm Metab Res 5 (Suppl): 40-44

5. Horwitz DL, Starr JI, Mako ME, Blackard WE, Rubenstein AH (1975) Proinsulin, insulin and C-peptide concentrations in human portal and peripheral blood. J Clin Invest 55: 1278-1283

6. Stoll RW, Touber JL, Menahan LA, Williams RH (1970) Clearance of porcine insulin, proinsulin and connecting peptide by the isolated rat liver. Proc Soc Exp Biol Med III: 894-896

7. Kühl C, Faber OK, Hornnes P, Lindkaer Jensen S (1978) C-peptide metabolism and the liver. Diabetes 27 (Suppl 1): 197-200

8. Heding LG (1975) Radioimmunological determination of human C-peptide in serum. Diabetologia 11: $541-548$

9. Kuzuya H, Blix PM, Horwitz DL, Rubenstein AH, Steiner DF, Binder C, Faber OK (1977) Heterogeneity of circulating C-peptide. J Clin Endocrinol Metab 44: 952-962

10. Kaneko T, Oka H, Munemura M, Oda T, Yamashita U, Suzuki S, Yanaihara N, Hashimoto T, Yanaihara C (1974) Radioimmunoassay of human proinsulin C-peptide using synthetic human connecting peptide. Endocrinol Jpn 21: 141-145

11. Beischer W, Keller L, Maas M, Schiefer E, Pfeiffer EF (1976) Human C-peptide. Part I: Radioimmunoassay. Klin Wochenschr 54: $709-715$

12. Faber OK, Markussen J, Naithani VK, Binder C (1976) Production of antisera to synthetic benzyloxycarbonyl-C-peptide of human proinsulin. Hoppe-Seyler's Z Physiol Chem 357:751-757

13. Faber OK, Binder C, Markussen J, Heding LG, Naithani VK, Kuzuya H, Blix P, Horwitz DL, Rubenstein AH (1978) Characterization of seven C-peptide antisera. Diabetes 27 (Suppl 1): 170-177

14. Caygill CPJ, Gaines Das RE, Bangham DR (1980) Use of a common standard for comparison of insulin C-peptide measurements by different laboratories. Diabetologia 18: 197-204

15. Block MB, Mako ME, Steiner DF, Rubenstein AH (1972) Circulating C-peptide immunoreactivity. Studies in normal and diabetic patients. Diabetes 21: 1013-1026

16. Block MB, Mako ME, Steiner DF, Rubenstein AH (1972) Diabetic ketoacidosis: evidence for C-peptide and proinsulin secretion following recovery. J Clin Endocrinol Metab 35: 402-406

17. Ludvigsson J, Heding LG (1978) Beta-cell function in children with diabetes mellitus. Diabetes 27 (Suppl 1): 230-234

18. Heinze E, Kohne, E, Meissner C, Beischer W, Teller WM, Kleinhauer $E$ (1979) Hemoglobin $A_{1 c}$ in children with long standing and newly diagnosed diabetes mellitus. Acta Paediatr Scand 68: 609-612

19. Menchini M, Meschi F, Lambiase R, Puzzovio M, Del Guercio MJ, Chiumello G (1980) C-peptide response to arginine stimulation in diabetic children. J Pediatr 96:362-366

20. Madsbad S, Kranup T, Regeur L, Faber OK, Binder C (1980) Insulin secretory reserve in insulin dependent patients at time of diagnosis and the first 180 days of insulin treatment. Acta Endocrinol 95: 359-363

21. Faber OK, Binder C (1977) Plasma C-peptide during the first year of insulin-dependent diabetes mellitus. In: Bajaj (ed) Proceedings of the IX Congress of the International Diabetes Federation, New Delhi, Excerpta Medica, Amsterdam Int Congr Ser 413: 149-154 
22. Faber OK, Binder C (1977) C-peptide response to glucagon. A test for the residual B-cell function in diabetes mellitus. Diabetes 26 : $605-610$

23. Madsbad S, Faber OK, Binder C, McNair P, Christiansen C, Transbøl I (1978) Prevalence of residual beta-cell function in insulin-dependent diabetics in relation to age at onset and duration of diabetes. Diabetes 27 (Suppl 1): 262-264

24. Ludvigsson J, Heding LG (1976) C-peptide in children with juvenile diabetes. Diabetologia 12:627-630

25. Hendriksen C, Faber OK, Drejer J, Binder C (1977) Prevalence of residual $\mathrm{B}$-cell function in insulin-treated diabetics evaluated by the plasma C-peptide response to intravenous glucagon. Diabetologia 13: 615-619

26. Grajwer LA, Pildes RS, Horwitz DL, Rubenstein AH (1977) Control of juvenile diabetes mellitus and its relationship to endogenous insulin secretion as measured by C-peptide immunoreactivity. J Pediatr 90: 42-48

27. Eff C, Faber O, Deckert T (1978) Persistent insulin secretion, assessed by plasma C-peptide estimation in long-term juvenile diabetics with a low insulin requirement. Diabetologia 15:169-172

28. Gepts W, Mey De J (1978) Islet-cell survival determined by morphology. Diabetes 27:251-262

29. Binder C, Christiansen JS, Faber O, Lauritsen T, Madsbad S, Svendsen PAa (1981) La fonction restante des cellules beta chez les diabetiques insulino-dependants - Preservation et regeneration. Journ Annu Diabetol Hotel-Dieu : 87-96

30. Madsbad S, Kratup T, Faber OK, Binder C, Regeur L (1982) The transient effect of strict glycaemic control on B cell function in newly diagnosed Type I (insulin-dependent) diabetic patients. Diabetologia 22: 17-22

31. Mirouze J, Selam JL, Pham TC, Mendoza E, Orsetti A (1978) Sustained insulin-induced remissions of juvenile diabetes by means of an external artificial pancreas. Diabetologia 14: 223-227

32. Madsbad S, Krarup T, Regeur L, Faber OK, Binder C (1981) Effect of strict blood glucose control on residual B-cell function in insulin-dependent diabetics. Diabetologia 20: 530-534

33. Krarup T, Madsbad S, Moody AJ, Regeur L, Faber OK, Holst JJ, Sestoft L (1982) Diminished immunoreactive gastric inhibitory polypeptide (IR-GIP) response to a meal in newly diagnosed Type 1 (insulin-dependent) diabetics. J Clin Endocrinol Metab, (in press)

34. Andersson A, Westman J, Hellerstrøm C (1974) Effects of glucose on the ultrastructure and insulin biosynthesis of isolated mouse pancreatic islets maintained in tissue culture. Diabetologia 10: $743-753$

35. Ludvigsson J, Säfwenberg J, Heding LG (1977) HLA-Types, Cpeptide and insulin antibodies in juvenile diabetes. Diabetologia 13: $13-17$

36. Canivet B, Harter M, Viot G, Balarac N, Krebs BP (1980) Residual beta-cell function in insulin-dependent diabetics: evaluation by circadian determination of C-peptide immunoreactivity. J Endocrinol Invest 3: 107-111

37. Buschard K, Madsbad S, Rygaard J (1982) Suppressor cell activity in patients with newly diagnosed insulin-dependent diabetes mellitus. A prospective study. J Clin Lab Immunol 8: 19-23

38. Bottazzo GF, Flovin-Christensen A, Doniach D (1974) Islet-cell antibodies in diabetes mellitus with autoimmune polyendocrine deficiencies. Lancet 2: 1279-1283

39. Irvine WJ, McCallum CJ, Gray RS, Campbell CJ, Duncan LJP, Farguhar JW, Waughan H, Morris PJ (1977) Pancreatic islet-cell antibodies in diabetes mellitus correlated with the duration and type of diabetes, coexistent autoimmune disease and HLA type. Diabetes 26: 138-147

40. Madsbad S, Bottazzo GF, Cudworth AG, Dean B, Faber OK, Binder C (1980) Islet-cell antibodies and beta-cell function in insulindependent diabetics. Diabetologia 18: 45-47

41. Theophanides CG, Pyke DA, Watkins PJ (1978) Islet function in diabetics with peristent islet cell antibodies. Diabetes 27 (Suppl 1): 265-266

42. Crossley JR, James AG, Elliott RB, Berryman CC, Edgar BW
(1981) Residual B-cell function and islet cell antibodies in diabetic children. Pediatr Res 15:62-65

43. Lernmark $\AA$, Freedman ZR, Hofmann C, Rubenstein AH, Steiner DF, Jackson RL, Winter RJ, Traisman HS (1978) Islet-cell-surface antibodies in juvenile diabetes mellitus. N Engl J Med 299: 375-380

44. Lernmark $\AA$, Hägglöf $B$, Freedman Z, Irvine J, Ludvigsson J, Holmgren $G$ (1981) A prospective analysis of antibodies reacting with pancreatic islet cells in insulin-dependent diabetic children. Diabetologia 20: 471-474

45. Huang S-W, Maclaren NK (1976) Insulin-dependent diabetes: a disease of autoaggression. Science 192: 64-66

46. Pozzilli P, Gorsuch A, Sensi M, Bottazzo GF, Cudworth AG (1979) Evidence for raised $\mathrm{K}$ cells levels in Type 1 diabetes. Lancet ii: $173-175$

47. Buschard K, Rygaard J, Lund E (1976) The inability of a diabetogenic virus to induce diabetes mellitus in athymic (nude) mice. Acta Pathol Microbiol Scand (C) $84 ; 299-303$

48. Jansen FK, Müntefering H, Schmidt WAK (1977) Virus induced diabetes and the immune system. I. Suggestion that appearance of diabetes depends on immune reactions. Diabetologia 13: 545-569

49. Buschard K, Röpke C, Madsbad S, Mehlsen J, Sørensen TB, Rygaard $\mathbf{J}$ (1983) Alterations of peripheral lymphocyte subpopulations in patients with insulin-dependent (Type 1) diabetes mellitus. J Clin Lab Immunol 10: 127-132

50. Buschard K, Madsbad S, Rygaard J (1980) Depressed suppressor cell activity in patients with newly diagnosed insulin-dependent diabetes mellitus. Clin Exp Immunol 41: 25-32

51. Buschard K, Madsbad S, Rygaard I (1982) Suppressor cell activity and beta-cell function in insulin-dependent patients. Acta Pathol Microbiol Scand 90: 53-57

52. Elliott RB, Crossby JR, Bergman CC, James AG (1981) Partial preservation of pancreatic B-cell function in children with diabetes. Lancet 2: 1-4

53. Kloppel G (1976) 'Insulin' induced insulinitis. Acta Endocrinol 83 (Supp1 205): 107-121

54. Lecompte PM, Steinke J, Soldner JS, Renold AE (1966) Changes in the islets of Langerhans in cows injected with heterologous and homologous insulin. Diabetes 15:586-596

55. Morgan CR, Carpenter A-M, Lazarow A (1965) Effect of insulin antibodies on pancreatic islet insulin and beta-cell granule content. Anat Rec 153: 49-54

56. Gerbitz K-D, Kemmler W, Edelmann A, Summer J, Mehnert H, Wieland OH (1979) Free insulin, bound insulin, C-peptide and the metabolic control in juvenile onset diabetics: comparison of $\mathrm{C}$ peptide secretors and non-secretors during 24 hours conventional insulin therapy. Eur J Clin Invest 9: 475-483

57. Yue DK, Baxter RC, Turtle JR (1978) C-peptide secretion and insulin antibodies as determinants of stability in diabetes mellitus. Metabolism 27: 35-44

58. Gonen B, Goldman J, Baldwin D, Goldberg RB, Ryan WG, Blix PM, Schanzlin D, Fritz KJ, Rubenstein AH (1979) Metabolic control in diabetic patients. Effect of insulin-secretory reserve (measured by plasma C-peptide levels) and circulating insulin antibodies. Diabetes 28: 749-753

59. Madsbad S, Alberti KGMM, Binder C, Burrin JM, Faber OK, Krarup T, Regeur L (1979) Role of residual secretion in protecting against ketoacidosis in insulin-dependent diabetes. Br Med J 2: 1257-1259

60. Asplin CM, Hartog M, Goldie DJ, Alberti KGMM, Binder C, Faber OK (1979) Diurnal profiles of serum insulin, C-peptide and blood intermediary metabolites in insulin treated diabetics, their relationship to the control of diabetes and the role of endogenous insulin secretion. Q J Med, New Series XLVIII, no.190: 343-360

61. Madsbad, S, Faber OK, Binder C, Alberti KGMM, Lloyd B (1981) Diurnal profiles of intermediary metabolites in insulin-dependent diabetes and their relationship to different degrees of residual beta-cell function. Acta Diabetol Lat 18: 115-121

62. Faber OK, Binder C (1977) B-cell function and blood glucose con- 
trol in insulin dependent diabetics within the first month of insulin treatment. Diabetologia 13:263-268

63. Madsbad, S, Hilsted J, Krarup T, Sestoft L, Christensen NJ, Faber OK, Tronier B (1982) Hormonal, metabolic and cardiovascular responses to hypoglycaemia in Type 1 (insulin-dependent) diabetes with and without residual $\mathrm{B}$ cell function. Diabetologia 23: 499-504

64. Mirel RD, Ginsberg-Fellner F, Horwitz DL, Rayfield EJ (1980) Cpeptide reserve in insulin-dependent diabetes. Comparative responses to glucose, glucagon and tolbutamide. Diabetologia 19: $183-188$

65. Lohmann D, Ellorhaoui M, Verlohren H-J (1977) Reduced insulin response in diabetes - a quantitative or a qualitative problem. Horm Metab Res 9: 444-447

66. Lauritzen T, Christiansen JS, Madsbad S, Faber OK, Binder C, Svendsen PAa (1980) Beta-cell secretion during glucose square wave stimulation in IDDM. Acta Endocrinol Suppl 237: 54 (Abstract)

67. Madsbad S, Krarup T, Tronier B, Faber OK, Regeur L (1982) Proinsulin in insulin-dependent (Type 1) diabetes in relation to residual beta-cell function and degree of glycaemic control. Acta Endocrinol 100 (Suppl 247): 44

68. Heding LG (1977) Specific and direct radioimmunoassay for human proinsulin in serum. Diabetologia 13: 467-474

69. Madsbad S, Faber OK, Kurtz A, Krarup T, Regeur L, Tronier B, Ørskov H, Binder C, Alberti KGMM (1982) The significance of the portal insulin secretion in insulin dependent patients with residual B-cell function: a safeguard against hormonal and metabolic derangement. Clin Endocrinol 16:605-613

70. Shima K, Tanaka R, Morishita S, Tarui S, Kamahara Y, Nishikawa M (1977) Studies on the etiology of brittle diabetes. Relationship between diabetic instability and insulinogenic reserve. Diabetes 26: 717-725

71. Raynolds C, Molnar GD, Horwitz DL, Rubenstein AH, Taylor WF, Jiang N-S (1977) Abnormalities of endogenous glucagon and insulin in unstable diabetes. Diabetes 26: 36-45

72. Cryer PE (1981) Glucose counterregulation in man. Diabetes 30: 261-264

73. Maher TD, Tanenberg RJ, Greenberg BZ, Hoffman JE, Doe RP, Goetz FC (1977) Lack of glucagon response to hypoglycemia in diabetic autonomic neuropathy. Diabetes 26: 196-200

74. Gerich JE, Langlois M, Noacco C, Karam JH, Forsham PH (1973) Lack of glucagon response to hypoglycemia in diabetes: evidence for an intrinsic pancreatic alpha cell defect. Science 182: 171-173

75. Samols E, Harrison J (1976) Intra-islet negative insulin-glucagon feedback. Metabolism 25 (Suppl 1): 1443-1447
76. Krarup T, Madsbad S, Hilsted J, Christensen NJ, Sestoft L, Schwartz TW (1982) Response of pancreatic polypeptide to hypoglycaemia in insulin-dependent diabetics with and without residual beta-cell function. Clin Endocrinol (in press)

77. Madsbad S, Hilsted J, Krarup T, Tronier B, Sestoft L (1982) Plasma somatostatin increase during hypoglycaemia in insulin-dependent patients with and without beta-cell function. Clin Endocrinol, (in press)

78. Hilsted J, Madsbad S, Krarup T, Sestoft L, Christensen NJ, Tronier B, Galbo H (1981) Hormonal, metabolic and cardiovascular responses to hypoglycaemia in diabetic autonomic neuropathy. Diabetes 30:626-633

79. Ginsberg HN (1977) Investigation of insulin resistance during diabetic ketoacidosis. Role of counterregulatory substances and effect of insulin therapy. Metabolism 26: 1135-1146

80. Larkins RG, Martin FIR, Alford FP, Chisholm DJ (1978) Relationship between $\mathrm{A}$ and $\mathrm{B}$ cell function in ketotic diabetic subjects. J Clin Endocrinol Metab 46: 131-139

81. Ludvigsson J, Heding LG, Larsson Y, Leander E (1977) C-peptide in juvenile diabeties beyond the postinitial remission period. Acta Paediatr Scand 66: 177-184

82. Beischer W, Kerner W, Raptis S, Keller L, Beischer B, Pfeiffer EF (1978) Insulin therapy in relation to circulating C-peptide levels. Diabetes 27 (Suppl 1): 235-240

83. Ikeda Y, Ando N, Minami N, Ide Y (1975) B-cell function of insulin-dependent young onset diabetics assessed by C-peptide immunoreactivity. Diabetologia 11: 351-352

84. Madsbad S, McNair P, Faber OK, Binder C, Christiansen C, Transbøl I (1980) Beta-cell function and metabolic control in insulin treated diabetics. Acta Endocrinol 93: 196-200

85. Tronier B, Madsbad S, Krarup T, Faber O (1982) Influence of strict glycaemic control and residual B-cell function for the A-cell function in insulin-dependent diabetics. Diabetologia: 22: 206 (Abstract)

86. Smith RBW, Pyke DA, Watkins PJ, Binder C, Faber OK (1979) Cpeptide response to glucagon in diabetics with and without complications. N Z Med J 89: 304-306

87. Bodansky HJ, Medbak S, Drury PL, Cudworth AG (1981) Plasma C-peptide in long-standing Type 1 diabetes with and without microvascular disease. Diabete Metab 7:265-269.

Dr. S. Madsbad

Hvidøre Hospital

Emiliekildevej 1

DK-2930 Klampenborg

Denmark 